\title{
Flood risk assessment and management: a case study in Rio de Janeiro
}

\author{
M. G. Miguez ${ }^{1}$, A. P. Veról ${ }^{1} \&$ L. Bianchini ${ }^{2}$ \\ ${ }^{1}$ Universidade Federal do Rio de Janeiro, Brazil \\ ${ }^{2}$ Universitat Politecnica de Catalunya, Spain
}

\begin{abstract}
Developing countries suffer with the growth of the so-called irregular cities. The lack of basic infrastructure and the inadequate urban growth management lead to urban flood problems. The concept of risk combines the probability of a hazard event with the consequences inflicted to a system. Thus, there are several possibilities of acting in flood risk mitigation: reducing the hazard and/or the system vulnerability. In this context, both structural measures and non-structural measures may be used. Traditional structural measures frequently were associated with river canalisation, dykes and dams. In the last past decades, the concepts of sustainable drainage systems have arisen, tending to control onsource runoff generation. Storage and infiltration measures are planned to diminish the impact of the urbanisation process on the hydrological cycle. Flood mapping, land use regulation and flood proofing constructions appear in this context as non-structural measures. More recently, the concept of river restoration appeared as an alternative. Rivers in more natural conditions and associated with a responsible land use tend to produce an environment with minor risks. In this context, this paper will discuss flood risks related to an urban environment and the choices related with the attempts to mitigate the problem. The Flood Risk Index (FRI), developed by Zonensein et al. (2008) is used to support a quantitative comparison of different design solutions. A case study concerning Mesquita City, in the metropolitan region of Rio de Janeiro, Brazil, is developed. The urban occupation of the city is very dense, with few open spaces and degraded areas. In the overall assessment, river restoration concepts, although limited by the built environment, produced a minor flood risk index, when compared with a traditional alternative.
\end{abstract}

Keywords: flood risk, risk assessment, river restoration. 


\section{Introduction}

Developing countries such as Brazil suffer with the growth of the so-called irregular cities composing slum areas. The lack of basic infrastructure and the inadequate urban growth management related to these areas is generally critical and one of the main consequences is that related to urban floods. As it could be observed with past experiences, traditional engineering solutions are not able to solve this problem alone. Besides, historical urban development experiences have not always looked to drainage problems. Although the urbanisation process usually aggravated floods (Wong and Brown [1]), it was not common to see the integration of new developments with sustainable urban drainage concepts. However, integrated actions over the urbanised watershed, aiming the urban space revitalisation and, when possible, recovering the associated natural environment and restoring river functions, could be achieved by incorporating hydraulic functions to urban elements (Miguez et al. [2]).

Hydraulic Engineering works usually consider an intrinsic safety factor associated with the return period of a design event. This is a common practice that equates a certain hydraulic need regarding the considered recurrence. However, this consideration is related with the probability of occurrence of a certain hazard event, which is certainly associated with the risk involved, but is not the risk itself. The concept of risk (Samuels [3]) combines the probability of a hazard event with the damage that is inflicted to the system subjected to this hazard. In this context, this paper will discuss flood risks related to an urban environment and the consequences of the choices related with the attempts to mitigate the problem.

Flood risk management is an approach for dealing with flood risk based on the notion that risks cannot be entirely taken away, but only partially reduced and always at the expense of other societal goals (Floodsite [4]). The aim of flood risk management is thus to reduce the consequences of floods, in ways that balance this aim against other considerations. The main purpose of this paper is to demonstrate, through a specific case study, that flood risks may be effectively reduced when considering river restoration aspects. The Flood Risk Index (FRI) developed by Zonensein et al. [5] is used as a support tool for quantitative comparison of scenarios design solutions. The interest area in this case refers to Mesquita City, in the metropolitan region of Rio de Janeiro. The urban occupation of the city is very dense, with few open spaces. This characteristic claims for a solution that is concerned about social urban space use, valorising degraded areas and giving it different possibilities of use.

\section{Risk assessment methodology}

Traditionally, flood risk assessments face some difficulties due to the subjective nature of the evaluation, to the large number of factors that interfere with risk and to the inexistence of a standardised methodology. Flood Risk Index (FRI), a quantitative multi-criteria index, ranging from 0 to 100 , is able to conjugate subindices related both to flood features and to local vulnerability and exposure 
characteristics. The application of the FRI requires the discretisation of the region of interest, i.e. an urban catchment, into small areas where the value of each indicator can be considered homogeneous.

The selected indicators to reflect flood properties include flood depth, a velocity factor (resulting from the maximum product of the water depth by the flow velocity), and a duration factor, associated with the permanence of the water level above a certain stage. In addition, indicators of dwelling density, income per capita, traffic and inadequate sanitation represent the estimated consequences of the flood, both tangible and intangible. Each of these factors must be converted into a scale ranging from 0 to 100 , according to specific normalisation functions. The relative importance of the indicators and subindices is expressed by weights associated to each of them. Finally, the formulation of FRI is composed by weighted summations and products, as presented in Zonensein et al. [5]. Eqn (1) shows the formulation of FRI adapted to this work. In this specific case, the indicators velocity factor and traffic were not considered in the formulation of FRI.

It can be observed that if either of the sub-indices is null, the FRI equals zero. It should be highlighted that the choice of indicators is not necessarily unyielding and may vary according to local features or to data availability/precision. On the other hand, the proposed formulation is applicable regardless of such particularities. This index constitutes a decision support tool that allows the determination and comparison of critical zones, and the assessment of the efficiency of different flood control measures, among other potential uses.

$$
F R I=\underbrace{\left[I_{D} \cdot p_{D}+I_{D F} \cdot p_{D F}\right]^{q_{F P}}}_{F P} \underbrace{\left[I_{D D} \cdot p_{D D}+I_{I n} \cdot p_{I n}+I_{I S} \cdot p_{I S}\right]^{q_{C}}}_{C}
$$

where:

FRI: Flood Risk Index (ranges from 0 to 100);

FP: flood properties sub-index (ranges from 0 to 100 );

$\mathrm{C}$ : consequences sub-index (ranges from 0 to 100);

$\mathrm{I}_{\mathrm{i}}$ : indicator $i$ (ranges from 0 to 100 );

$\mathrm{p}_{\mathrm{i}}$ : weight of indicator $i$ (ranges from 0 to 1 );

$\mathrm{q}_{\mathrm{i}}$ : weight of sub-index $i$ (ranges from 0 to 1 );

i: D-Depth; DF-duration factor; DD-dwelling density; In-income per capita; ISinadequate sanitation.

\section{Flood risk mitigation}

There are several possibilities of acting in flood risk mitigation. It is possible to work on the reduction of the hazard, what tends to be the most common action. Another possibility, however, is to diminish the system vulnerability. Both paths may be effective and the combination of both types of actions is desired, in order to have better and lasting results.

Two types of measures are considered when discussing flood risk mitigation: structural measures, usually related with controlling the hazard, what means 
reducing flood events critical characteristics; and non-structural measures, usually related with reducing exposure and vulnerability or increasing resilience. Traditional structural measures frequently were associated with river canalisation, dykes and dams. In the last past decades, the concepts of sustainable drainage systems have arisen (Woods-Ballard et al. [6]; Melbourne Water [7]), tending to consider distributed measures over the basin, controlling on-source runoff generation. This type of measures are planned to diminish the impact of the urbanisation process on the hydrological cycle (Coffman et al. [8]). Storage and infiltration measure take an important place in these arrangements. The concept of a sustainable drainage system also combines non-structural measures on the proposed design solutions. Some examples of this type of actions refer to flood mapping, land use regulation and flood proofing constructions.

More recently, another concept is also being considered in the flood risk scenario: the river restoration alternative (Gusmaroli et al. [9]; Dufour and Piégay [10]; Findlay and Taylor [11]). This alternative usually considers four pillars, with minor differences among the distinct approaches, which stand for maintenance of the natural hydrologic cycle and hydraulic risk control, fluvial morphology equilibrium, water quality and fluvial ecosystems restoration. Rivers in more natural conditions, when associated with a responsible land use planning, tend to produce a more harmonious environment, with minor risks. However, when talking about an urban area, it is very difficult to apply river restoration concepts. There are several limitations associated with the heavy watershed changes produced by the city growth. Nevertheless, it is possible to introduce some of the basic concepts, in order to have some environmental positive results, while controlling floods and diminishing city vulnerability. Recovering the connection of the river with its flood plains, relocating people in risky conditions, especially the ones living in sub-habitations over the river banks, acting over the watershed with sustainable urban drainage measures to control runoff generation (in order to provide a mimics of the natural water cycle results), may be some important actions to be held in the urban context. These measures may represent just a minor step towards an effective river restoration, but they may be a gain in the built environment.

\section{Case study}

Baixada Fluminense is an important region of the metropolitan area of Rio de Janeiro, Brazil. This area is known by its lowlands that spread over IguaçuSarapuí River plains. Dona Eugênia River catchment (Figure 1) has a drainage area of $18 \mathrm{~km}^{2}$ and is $10 \mathrm{~km}$ long, running down the hills until it reaches Sarapuí River, at the coastal plains. The first $4 \mathrm{~km}$ are in Nova Iguaçu City. The river spring is in Nova Iguaçu Natural Municipal Park, at an environmental preservation area called Gericinó. The subsequent $6 \mathrm{~km}$ are inside Mesquita City urban tissue. Throughout its $10 \mathrm{~km}$ long, the river passes through differentiated reaches, in which nature still presents itself preserved, in its upper reaches, and also presents degraded reaches, in the urban part of the catchment. 


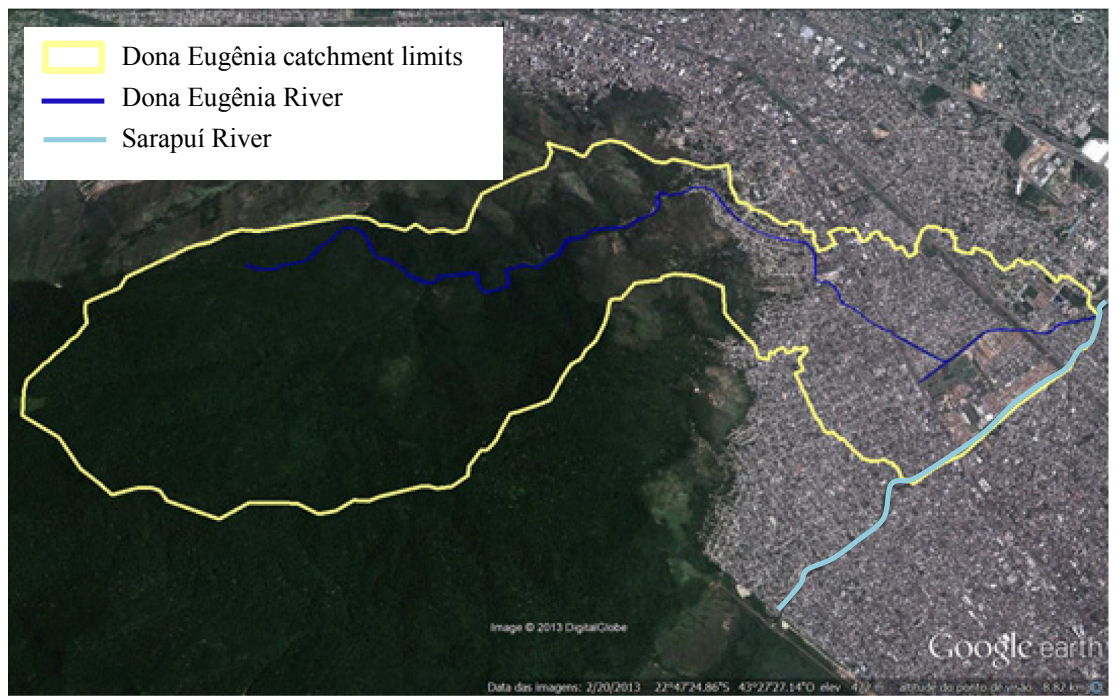

Figure 1: $\quad$ Dona Eugênia River Catchment (Google Earth, [12]).

The FRI was applied in the case study of Dona Eugênia river basin, using Census data from the Brazilian Institute of Geography and Statistics (IBGE [13]). The other data source consisted of flood simulation results carried out with the aid of MODCEL, a hydrodynamic and distributed hydrologic model, suitable for urban floods simulation, (Mascarenhas and Miguez [14]; Mascarenhas et al. [15]), regarding a 25-year return period rainfall event.

Weights were determined, in a first approach, using the experience of the authors, simulating the preferences of a decision maker. In general, there are three limiting factors for the applicability of the FRI: availability of data, existence of data with adequate precision, and limits of the normalisation scales. If data with adequate precision is available, the FRI is mostly limited by the normalisation of its indicators. As presented in Zonensein [5], the FRI is restricted to areas with conditions of dwelling density and income per capita similar to those found in the city of Rio de Janeiro, which was the basis for the construction of normalisation scales for these indicators. When applied to areas with significantly different conditions, which is the case of this study, the choice of indicators and their normalisation scales should be reviewed. However, the index structure is still valid, with no restrictions, regardless of the domain. Considering this, FRI was adapted to this case study. Table 1 presents the normalisation for the Depth indicator, associating its values with a scale of importance varying from 0 through 100 . Between the established thresholds, linear interpolation may be applied.

To calculate the Duration Factor, it was considered that t10, t30 and t50 are the times (in minutes) during which an area remains flooded with over 10, 30 and $50 \mathrm{~cm}$, respectively, and that these intervals (and associated depths) are 
representative of the long-term effects of a flood over pedestrians, vehicles and residences, in that order.

Table 1: Flood depth normalisation thresholds (Adapted from Zonensein $[5])$.

\begin{tabular}{ccl}
\hline $\begin{array}{c}\text { Depth } \\
\text { (cm) }\end{array}$ & \multicolumn{1}{c}{ Effect } \\
\hline$<10$ & 0 & $\begin{array}{l}\text { The curb is usually from } 10 \text { to } 15 \mathrm{~cm} \text { height, thus } 10 \mathrm{~cm} \text { of water is } \\
\text { limited to the streets. }\end{array}$ \\
\hline 25 & 50 & $\begin{array}{l}\text { With } 25 \mathrm{~cm}, \text { inundation fills streets, parks, sidewalks, yards and } \\
\text { parking lots. It can slow or interrupt traffic and invade simpler } \\
\text { houses, with doors-sill next to the sidewalk level. }\end{array}$ \\
\hline 50 & 75 & $\begin{array}{l}50 \mathrm{~cm} \text { the water will very probably have already invaded the interior } \\
\text { of houses, causing damages to its structure and content. }\end{array}$ \\
\hline 75 & 90 & $\begin{array}{l}\text { At this height the water reaches practically all the goods in the } \\
\text { interior of the houses. }\end{array}$ \\
\hline$>125$ & 10 & $\begin{array}{l}\text { This depth has not only reached goods, but also it is enough to cause } \\
\text { drowning. }\end{array}$ \\
\hline
\end{tabular}

The Dwelling Density indicator intends to be an estimate for the amount of people and assets affected by flood. It was considered that $0 \mathrm{dwelling} / \mathrm{km}^{2}$ is the value with the least potential to suffer damage during floods, and that 5000 dwellings $/ \mathrm{km}^{2}$, which corresponds to the threshold of the variable's third quartile, in the city of Mesquita, is associated with the maximum value. A linear interpolation was applied between these extremes. The Income per capita indicates the total value of the affected properties and its contents. Where the communities suffer from inadequate sanitation, there is a higher chance of water borne diseases transmission. The normalisation of the indicator Inadequate sanitation is considered that $0 \%$ of domiciles with inadequate sanitation is the most favorable value of this parameter $\left(\mathrm{I}_{\mathrm{IS}}^{\mathrm{C}}=0\right)$ whereas $100 \%$ of inadequate sanitation is the least favorable value $\left(\mathrm{I}_{\mathrm{IS}}^{\mathrm{C}}=100\right)$. Inadequate sanitation is a variable measured by Brazilian Census.

The evaluation of the FRI concerned three areas: all the urban catchment, the fluvial corridor and the city centre, where the City Hall is located (Figure 2).
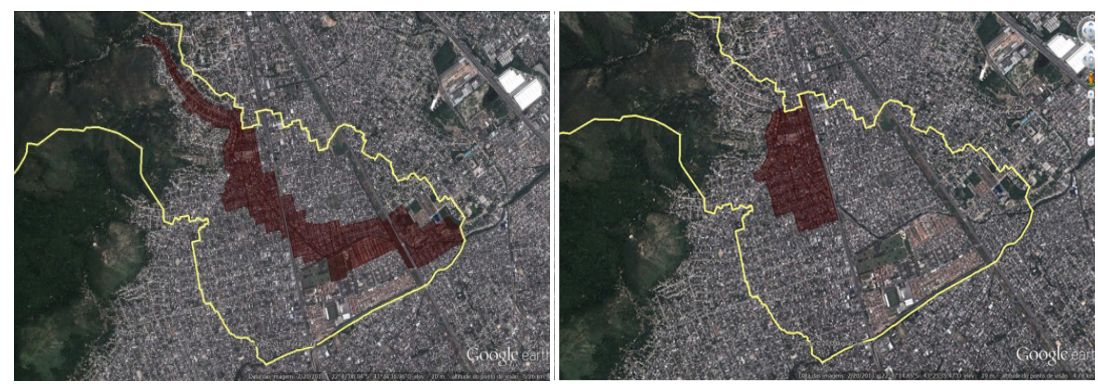

Figure 2: $\quad$ (a) Fluvial Corridor (b) City Centre (Google Earth [12]). 
The following scenarios were evaluated: present, implementation of a dam and river restoration. The results are presented in the next topics.

\subsection{Present scenario}

Mesquita has many infrastructure problems. In the most populated areas of the city, there are numerous illegal housing subdivisions. Even regular lots, but resulting from an intense fragmentation of the land appears frequently. Another important question is that, due to the lack of adequate housing programs, there are many houses occupying river banks (Figure 3). Rectifications and canalisations were works conducted in the majority of the rivers of Baixada Fluminense, changing a lot the lower fluvial reaches of the catchment. Dona Eugênia was one of these rivers, which had its morphology altered. Direct discharge of sewage and solid waste in the river, with visible environmental degradation is another problem. The recurrent problem of flooding affects about $80 \%$ of the population. In general terms, the degradation of the urban environment is a very critical situation, reflecting poor socio-economic aspects.
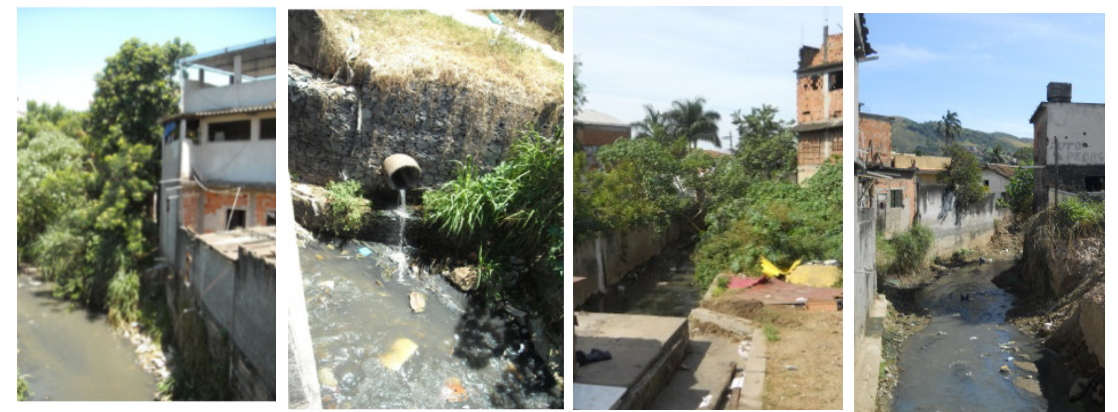

Figure 3: Illegal constructions along Dona Eugênia River (Veról [16]).

The FRI for this scenario showed the criticality of the region. For the urban part of the catchment, the obtained value was 20.6. Considering the fluvial corridor, the FRI was 23.2. For the centre part of the city, it was 34.0. The modelled flood map, for a rainfall design event of 25 -year return period, is showed in Figure 4.

\subsection{Dam scenario}

Taking the flooding situation into account, it was developed, at the 1990 decade, a Water Resources Master Plan for Iguaçu-Sarapuí Rivers, focusing on flood control. The main propositions were traditional drainage measures, including the construction of a flood control dam at the upstream reach of Dona Eugênia River. This Master Plan was later revised, with the aim of applying sustainable urban drainage measures to the region, such as the use of urban parks, varying from the protection of the banks to temporary reservoirs. Yet, the solution for 
river overflows continued dependent on the designed dam, proposed in the first study.

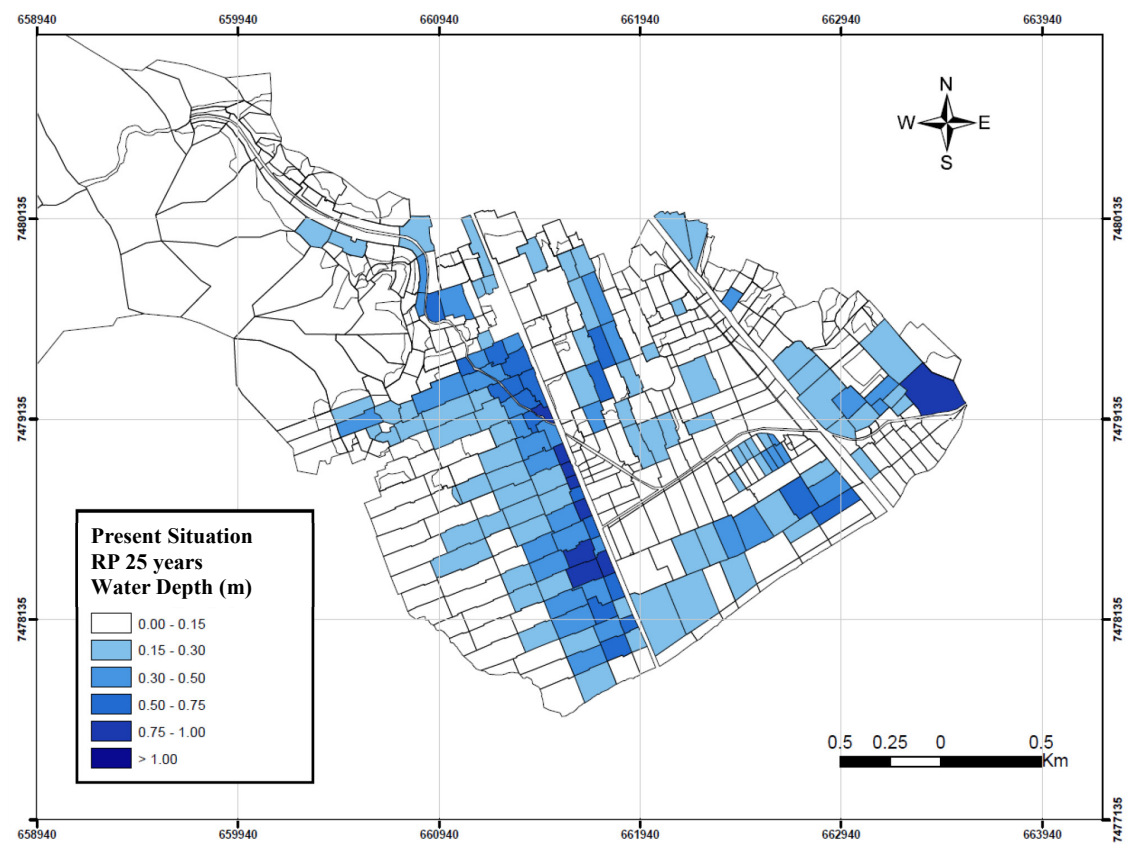

Figure 4: $\quad$ Flood map - present situation - RP 25 years.

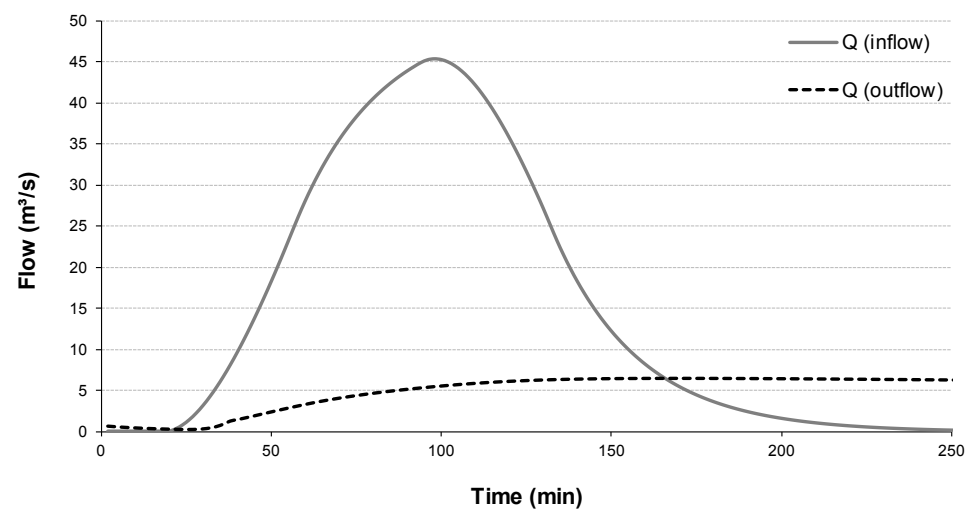

Figure 5: Hydrograph - flood control dam - RP 25 years (INEA [17]).

The dam was adjusted to the current situation (more than 10 years later) and the simulation of its operation indicated a reduction of $84 \%$ in Dona Eugênia River water levels (Figure 5). However, this fact is not replicated to the river 
surrounding areas, because the river banks occupation and the urban floods caused by the excess of runoff are not affected by the dam effects. For the urban part of the catchment, the FRI obtained value was 19.5. Considering the fluvial corridor, it was 19.2; in the centre part of the city, it was 27.4.

\subsection{River restoration scenario}

A River Restoration (RR) scenario, although even partially, was proposed, considering new concepts of sustainable urban drainage, urban planning and development actions. The aim of this proposition was to complement or replace past development and traditional solutions by new concepts which consider fluvial ecosystems needs. Thus, four different approaches were proposed for the river treatment, as shown in Figure 6.

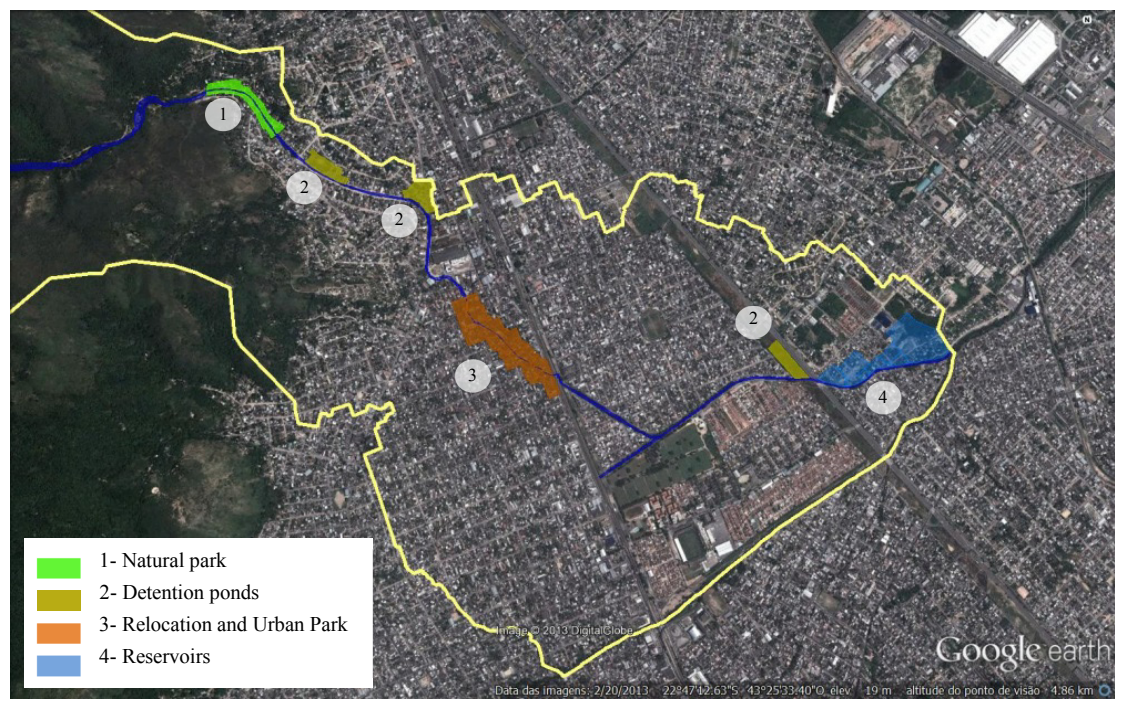

Figure 6: Areas affected by the river restoration process (Google Earth [12]).

At the upstream reach, a more natural composition was considered, with an extension of the natural park advancing inside the city (area 1). At the downstream reach, a wetland was proposed, for temporary storage as well as a quality control measure (area 4). This last effect was not assessed - it is a possibility to be further explored. In the middle reach of the river (area 3), an urban park, with recreational purposes, was proposed to substitute the irregular occupation of the river banks (Figure 7 and Figure 8). This area intended to fulfil two objectives: provide an artificial flood plain for the river; and give some space for relocating the population in flood proofing new buildings. At last, some urban interventions were introduced to act as detention reservoirs (area 2). 


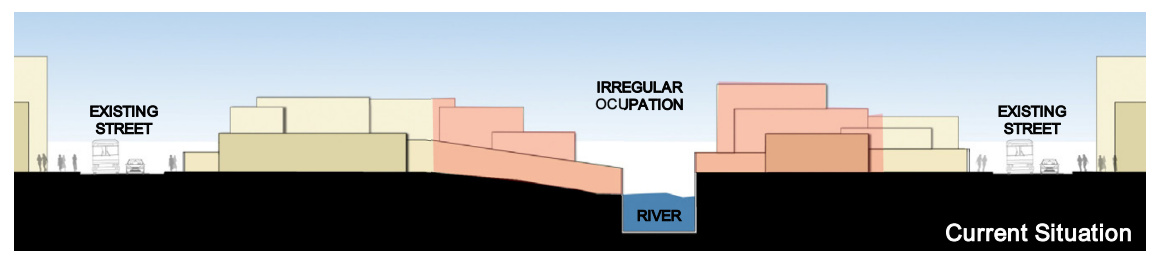

Figure 7: Section of the river in the middle part of the city (Costa et al. [18]).

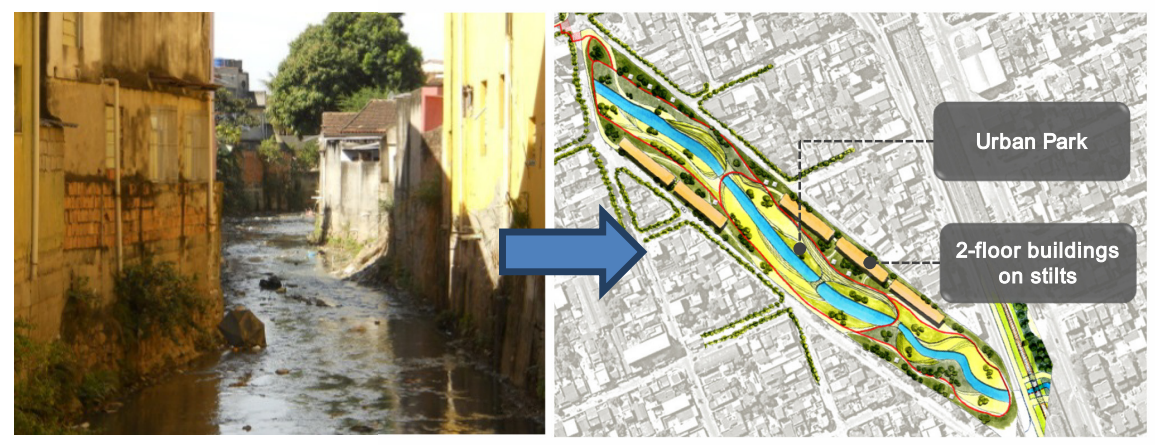

Figure 8: (a) Irregular occupation on the river banks (Veról [16]); (b) Design proposition considering an urban park and 2-floor buildings on stilts (Costa et al. [18]).

In this scenario, the FRI was 18.0 for the urban part of the catchment, 12.9 when considering only the fluvial corridor and 18.6; in the centre part of the city.

\subsection{Discussion of results}

As it was possible to see in the present situation scenario, the flood problem in Mesquita City is critical. There are records of frequent inundation and the mathematical modelling showed important areas below water, with water depths that were able to reach, in certain places, near 1 meter high, as it could be seen in the flood map of Figure 4. The centre of the city is very affected. Two important processes were verified: both major and minor drainage fail. River overflowing is responsible for flooding even the City Hall.

The proposition of a dam in the upstream reach of Dona Eugênia River was able to completely control river overflowing for a return period of 25 years. The discharges were all conducted inside the river channel. However, this measure does not act over the surface flows, the minor drainage still fails and there are several parts of the city still inundated (with minor water depths, generally). One special effect noted is in a river reach corridor, near the centre of the city, where houses irregularly placed in the river banks act as dykes (Figure 8a), avoiding the connection of the river with the "flood plains". In this area, the runoff generated 
and not collected by the minor drainage accumulates in the streets, without reaching the river.

On the other side, when the river restoration was considered, the designed project was also capable to maintain the river inside its banks, although with almost no freeboard. However, because of the possibility of acting in the riverine areas, opening spaces for temporary storage while re-connecting the river to its flood plains, part of the minor drainage problems were also solved. In the overall assessment, river restoration concepts, although limited by the built environment, produced a minor risk index, when compared with the dam alternative. Table 2 summarises the obtained results.

Table 2: $\quad$ FRI results.

\begin{tabular}{cccc}
\hline Scenario & $\begin{array}{c}\text { Urban } \\
\text { Catchment }\end{array}$ & $\begin{array}{c}\text { Fluvial } \\
\text { Corridor }\end{array}$ & $\begin{array}{c}\text { City } \\
\text { Centre }\end{array}$ \\
\hline Present & 20.6 & 23.2 & 34.0 \\
\hline Dam & 19.5 & 19.2 & 27.4 \\
\hline $\boldsymbol{R} R$ & 18.0 & 12.9 & 18.6 \\
\hline
\end{tabular}

\section{Concluding remarks}

Few data regarding flood risk analysis or flood damage evaluation is available for this region, as for most of the Brazilian territory. However, the FRI managed to quantify flood risk by integrating various factors, expressed by easily available indicators aggregated in a simple formulation. The results that can be obtained may allow rating, identifying, and comparing critical zones, as well as simulating the impact of flood control measures scenarios. The index structure is sufficiently flexible to express different flood risk perceptions, such as the decision makers, experts' or population's, by either varying the weights' or the chosen indicators' set. Considering FRI results, from the formulation used in this paper, critical flood problems in Dona Eugênia catchment are restricted to particular and important areas, like Mesquita city centre, while most of the catchment could be rated as a low risk region. Flooding in the watershed is the result from major and minor drainage failures. The problem at those critical zones may be addressed with measures focusing either on flood hazard mitigation or on vulnerability and exposure reduction. The impacts of such measures, represented by changes in the associated indicators were forecasted with new FRI simulation. A more traditional approach, regarding the introductions of a dam, was able to eliminate $100 \%$ of the river overflow. However, risk reduction on the city centre was something about $20 \%$, because riverbank occupation was not addressed, and there was not any effect over the superficial flows. The river restoration alternative, although only partially possible, reconnecting the flood plains to the river and freeing its banks, was also able to maintain the main flow inside the river channel and reduced flood risk in the city centre in approximately $45 \%$. These newer techniques, associated with the concept of sustainable urban drainage, tends to treat the problem in an integrated context, focusing on distributed actions, in order to restore (as possible) 
infiltration and storage capacity of the natural basin as well as river natural hydraulic functions. The obtained results must not be seen as final ones. The river restoration scenario should be further developed, in order to introduce on-source control measures for an even more effective hydrological result. Urban development should be carried on producing low hydrologic impacts and land use occupation should also be controlled, in order to minimise river and city degradation.

\section{Acknowledgement}

The authors acknowledge CNPq for the scholarships.

\section{References}

[1] Wong, T. and Brown, R. Transitioning to Water Sensitive Cities: Ensuring Resilience through a new Hydro-Social Contract. In: 11th International Conference on Urban Drainage. Edinburgh, UK: IAHR/IWA, 2008.

[2] Miguez, M.G.; Mascarenhas, F.C.B. and Magalhães, L.P.C. Multifunctional landscapes for urban flood control in developing countries. International Journal of Sustainable Development and Planning, 2(2), pp. 153-166, 2007.

[3] Samuels, P., Flood Risk Analysis and Management - Achieving Benefits from Research. In: European Conference on Floods. Viena, Áustria, 2006.

[4] Floodsite. Integrated Flood Risk Analysis and Management Methodologies. Available from: $<\mathrm{http}: / /$ www.floodsite.net $>$.

[5] Zonensein, J.; Miguez, M.G.; Magalhães, L.P.C.; Valentin M.G. and Mascarenhas, F.C.B. Flood Risk Index as an Urban Management Tool. In: 11th International Conference on Urban Drainage. Edinburgh, UK: IAHR/IWA, 2008.

[6] Woods-Ballard, B.; Kellagher, R.; Martin, P.; Bray, R. and Shaffer, P. The SUDS Manual. CIRIA C697. London: CIRIA, 2007.

[7] Melbourne Water. WSUD Engineering Procedures: Stormwater. Collingwood, Australia: CSIRO Publishing, 2005

[8] Coffman, L.S., Cheng, M., Weinstein, N. and Clar, M. Low-Impact Development Hydrologic Analysis and Design. In: Proceedings of the 25th Annual Conference on Water Resources Planning and Management Chicago-Illinois. New York: American Society of Civil Engineering, 1998.

[9] Gusmaroli, G.; Bizzi, S. and Lafratta, R. L'approccio della Riqualificazione Fluviale in Ambito Urbano: Esperienze e Opportunittà. In: $4^{\circ}$ Convegno Nazionale di Idraulica Urbana/Acqua e Città. Venice, Italy, 2011.

[10] Dufour, S. and Piégay, H. From the Myth of a Lost Paradise to Targeted River Restoration: Forget Natural References and Focus on Human Benefits. River Research and Applications, 25, pp. 568-581, 2009.

[11] Findlay, S. J. and Taylor, M.P. Why rehabilitate urban river systems? Area, 38(3), pp. 312-325, 2006.

[12] Google Earth, www.google.com/earth. 
[13] IBGE - Brazilian Institute of Geography and Statistics. Demographic Census 2010. Rio de Janeiro, 2010.

[14] Mascarenhas, F.C.B. and Miguez, M.G. Urban Flood Control through a Mathematical Cell Model. Water International, 27(2), pp. 208-218, 2002.

[15] Mascarenhas, F.C.B.; Toda, K.; Miguez, M.G.; Inoue, K. Flood Risk Simulation. WIT PRESS: Southampton and Boston, 436p, 2005.

[16] Veról, A.P. Pictures of Dona Eugênia catchment, 2012.

[17] INEA (Instituto Estadual do Ambiente). Plano Diretor de Recursos Hídricos, Controle de Inundações e Recuperação Ambiental da Bacia do Rio Iguaçu/Sarapuí. PDIS-RE-013-R0. Volume 2. Rio de Janeiro, RJ, 2009.

[18] Costa, I. A.; Nascimento, M.B.; Furtado, V.M. Revitalização do rio Dona Eugênia: o estudo de caso da cidade de Mesquita. Jornada de Iniciação Científica da UFRJ. Rio de Janeiro, 2011. 